\title{
Activation of the cGMP Pathway in Dopaminergic Structures Reduces Cocaine-Induced EGR-1 Expression and Locomotor Activity
}

\author{
Peggy Jouvert, ${ }^{1}$ Marie-Odile Revel, ${ }^{1}$ Anelise Lazaris, ${ }^{2}$ Dominique Aunis, ${ }^{1}$ Keith Langley, ${ }^{1}$ and Jean Zwiller ${ }^{1}$ \\ ${ }^{1}$ Institut National de la Santé et de la Recherche Médicale, Unité 575, Centre de Neurochimie, 67084 Strasbourg, France, and ${ }^{2}$ Unité Mixte de Recherche \\ 7521 Centre National de la Recherche Scientifique, 67000 Strasbourg, France
}

\begin{abstract}
Nitric oxide (NO) and the C-type natriuretic peptide (CNP) exert their action on brain via the cGMP signaling pathway. NO, by activating soluble guanylyl cyclase, and CNP, by stimulating membrane-bound guanylyl cyclase, cause intracellular increases of cGMP, activating cGMP-dependent protein kinases (PKGs). We show here that injection of CNP into the rat ventral tegmental area strongly reduced cocaine-induced egr-1 expression in the nucleus accumbens in a dose-dependent manner. The effect of CNP was reversed by the previous injection of a selective PKG inhibitor, KT5823. Activation of PKG by 8-bromo-cGMP reduced, like CNP, cocaine-induced gene transcription in dopaminergic structures. To confirm the involvement of $\mathrm{PKG}$, this was overexpressed in either the mesencephalon or the caudateputamen. Using the polyethyleneimine delivery system, an active protein was expressed by injecting a plasmid vector containing the human PKG-I $\alpha$ cDNA. PKG was overexpressed in dopaminergic and GABAergic neurons when the plasmid was injected in the ventral tegmental area, whereas overexpression was observed in medium spiny GABAergic neurons and in both cholinergic and GABAergic interneurons when the PKG vector was injected into the caudate-putamen. Activation of the overexpressed PKG reduced cocaineinduced egr-1 expression in dopaminergic structures and affected behavior (i.e., locomotor activity). These effects were again reversed by previous injection of the selective PKG inhibitor. The current data suggest that NO and the neuropeptide CNP are potential regulators of cocaine-related effects on behavior.
\end{abstract}

Key words: cGMP-dependent protein kinase; CNP peptide; cocaine; dopaminergic neurotransmission; immediate-early gene egr-1; psychostimulant

\section{Introduction}

The signaling pathways that increase cGMP are implicated in various aspects of brain physiology, including neurotransmission (Schmidt and Walter, 1994; Hofmann et al., 2000). The most extensively studied cGMP signal transduction pathway is that triggered by nitric oxide (NO) (Bredt and Snyder, 1990). The major intracellular target of $\mathrm{NO}$ is the heme group of soluble guanylyl cyclase (sGC), where it binds and promotes the synthesis of cGMP (Miki et al., 1977). In addition to NO/sGC, the atrial, brain, and C-type natriuretic peptides ANP, BNP, and CNP also increase cGMP synthesis, but by stimulating the membranebound GCs GC-A and GC-B, with CNP preferentially stimulating the GC-B receptor (Koller et al., 1991). CNP is predominantly located in the CNS (Garbers, 1992).

\footnotetext{
Received Nov. 17, 2003; revised 0ct. 13, 2004; accepted 0ct. 13, 2004.

We thank Serge Gobaille for help with microinjection techniques and Dr. Guy Roussel and Sylvie Dirrig-Grosch (Service de Microscopie Confocale, IFR037, Strasbourg, France) for help with immunohistological techniques. We are very grateful to Dr. E. Dauty and Prof. J. P. Behr (Unité Mixte de Recherche 7514, Faculté de Pharmacie, Illkirch, France) for the generous gift of $22 \mathrm{kDa}$ PEl.

Correspondence should be addressed to Dr. J. Zwiller, Institut National de la Santé et de la Recherche Médicale, Unité 575, Centre de Neurochimie, 5 rue Blaise Pascal, 67084 Strasbourg Cedex, France. E-mail: zwiller@neurochem.u-strasbg.fr.

D0I:10.1523/JNEUROSCI.1398-04.2004

Copyright $(\odot 2004$ Society for Neuroscience $\quad 0270-6474 / 04 / 2410716-10 \$ 15.00 / 0$
}

cGMP effects are primarily mediated by the activation of cGMP-dependent protein kinases (PKGs). Two distinct mammalian PKGs, PKG-I and PKG-II, have been identified, as well as two splice variants of PKG-I (PKG-I $\alpha$ and $-\mathrm{I} \beta$ ). In the brain, PKG-I is highly expressed in cerebellar Purkinje cells and, to a lesser extent, in striatal medium spiny neurons (Lohmann et al., 1981; Ariano, 1983; De Camilli et al., 1984). PKG-II is a membrane-associated protein that is expressed throughout the brain (Uhler, 1993; Jarchau et al., 1994; de Vente et al., 2001).

The administration of psychomotor stimulants alters neuronal gene expression in the brain, and these changes are thought to mediate behavioral effects associated with chronic drug abuse (Nestler, 2001). Acute cocaine administration has been shown to elicit rapid and transient induction of several immediate-early genes (IEGs) in brain neurons, including egr-1, c-fos, junB, and hVH5 (Hope et al., 1992; Moratalla et al., 1992; Bhat and Baraban, 1993; Torres and Rivier, 1994; Daunais and McGinty, 1996; Humblot et al., 1998; Thiriet et al., 1998; Jouvert et al., 2002). Because many IEGs encode transcription factors, it has been suggested that they act as molecular switches that coordinate changes in gene expression underlying neuronal plasticity (Sheng and Greenberg, 1990; Morgan and Curran, 1991). The psychostimulant and locomotor effects of cocaine have been attributed mainly to increased dopamine (DA) neurotransmission in the dorsal 
[caudate-putamen $(\mathrm{CPu})$ ] and ventral [nucleus accumbens (NAc)] striatum (Di Chiara and Imperato, 1988; Koob and Bloom, 1988; Kuhar et al., 1991). In the striatum, IEG induction in response to cocaine occurs in medium spiny neurons, which constitute $90 \%$ of the striatal neuronal population and use GABA as their transmitter (Kita and Kitai, 1988).

In two previous studies, we have shown that both CNP and the NO generator sodium nitroprusside regulate the activity of DAergic neurons (Thiriet et al., 2001, 2002). Intracerebroventricular injection of these substances was found to inhibit both cocaine-induced extracellular DA increase and expression of several IEGs, including egr-1. In the present study, we characterize the site of action of CNP in DAergic structures and demonstrate that activation, or overexpression, of PKG-I is able to inhibit cocaine-induced egr-1 mRNA expression and locomotor activity.

\section{Materials and Methods}

Animals and injection procedures. Male Wistar rats (Janvier, Le GenestSt-Isle, France) 220-270 gm were housed with ad libitum access to food and water and maintained on a fixed $12 \mathrm{hr}$ light/dark schedule at $21^{\circ} \mathrm{C}$. All experiments were conducted in conformity with the European Community Council Directive. For implantation of guide cannulas, rats were anesthetized with ketamine $(100 \mathrm{mg} / \mathrm{kg}$, i.p. $)$ and placed in a stereotaxic frame. The guide cannulas were slowly lowered into the $\mathrm{CPu}$ at the following coordinates: anteroposterior, $0.3 \mathrm{~mm}$ to bregma; mediolateral, $3.5 \mathrm{~mm}$; dorsoventral, $-4.8 \mathrm{~mm}$ (Paxinos and Watson, 1997). Coordinates for implantation into the ventral tegmental area (VTA) were as follows: anteroposterior, $2.3 \mathrm{~mm}$ to lambda; mediolateral, $0.5 \mathrm{~mm}$; dorsoventral, $-7.7 \mathrm{~mm}$; coordinates for implantation into the substantia nigra (SN) were as follows: anteroposterior, $2.3 \mathrm{~mm}$ to lambda; mediolateral, $2 \mathrm{~mm}$; dorsoventral, $-6.5 \mathrm{~mm}$. The guide cannulas were permanently fixed to the skull with stainless steel screws and methacrylate cement. Experiments were performed $4 \mathrm{~d}$ after implantation. The correct placement of guide cannulas was verified by histological examination of tissue sections.

CNP (rat CNP-22; Sigma, St. Louis, MO) was administered into the brain using an Exmire syringe connected to a CMA100 microinjection pump (Carnegie Medicine, Stockholm, Sweden), with calibrated needles reaching the ventral coordinate $-5.8 \mathrm{~mm}$ for intra- $\mathrm{CPu}$ injection and $-8.7 \mathrm{~mm}$ for intra-VTA injection. Two microliters of CNP solution prepared in saline were administered at a flow rate of $1 \mu \mathrm{l} / \mathrm{min}$ into the right hemi- $\mathrm{CPu}$, whereas $2 \mu \mathrm{l}$ of vehicle was injected into the left one. The volume injected into each hemi-VTA was $0.5 \mu$ l. Fifteen minutes after $\mathrm{CNP}$ administration, animals were given an intraperitoneal injection of saline or cocaine ( $20 \mathrm{mg} / \mathrm{kg}$; Sigma).

Plasmid/polyethyleneimine (PEI) complexes were injected into the $\mathrm{CPu}, \mathrm{VTA}$, or $\mathrm{SN}$, as indicated above. PKG-I $\alpha$ cDNA was subcloned into the p513 vector, a derivative of the PSG5 mammalian expression vector, as described previously (Esteve et al., 2001). Vector $(7.5 \mu \mathrm{g})$ containing the PKG-I $\alpha$ cDNA or vector lacking a cDNA insert were complexed with $15 \mathrm{nmol}$ of linear $22 \mathrm{kDa}$ PEI in 5\% glucose solution. Mixtures were allowed to equilibrate for $15 \mathrm{~min}$ at room temperature. They were then injected $(0.5 \mu \mathrm{g}$ per injection) into the right VTA $(0.6 \mu \mathrm{l}), \mathrm{SNc}(0.6 \mu \mathrm{l})$, or $\mathrm{CPu}(2 \mu \mathrm{l})$ and with $0.5 \mu \mathrm{g}$ of vector lacking a cDNA insert into the left corresponding structure (Poulain et al., 2000). The ventral coordinate was $-7.5 \mathrm{~mm}$ for intra-SN injection and as indicated above for intra$\mathrm{CPu}$ and intra-VTA injection. PKG was activated by the subsequent injection of a $20 \mathrm{~mm}$ 8-bromo-cyclic GMP (Br-cG; Sigma) saline solution or inhibited by the injection under identical conditions of a 2 mM KT5823 (Calbiochem, La Jolla, CA) solution, according to the injection schedule shown in Figure 1. The injection volume was $0.5 \mu \mathrm{l}$ for the VTA and SNc and $1 \mu \mathrm{l}$ for the $\mathrm{CPu}$. Microinjections of equivalent volumes of vehicle were used as controls. Fifteen minutes after $\mathrm{Br}-\mathrm{cG}$ administration, animals were given an intraperitoneal injection of saline or $20 \mathrm{mg} / \mathrm{kg}$ cocaine.

Synaptosomal preparation. Synaptosomes were prepared from striata of untreated rats essentially as described previously (Morgan et al., 1971).

\section{TIME}

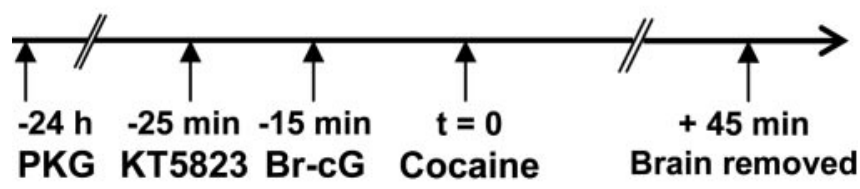

Figure 1. Schematic representation of injection schedule used for PKG overexpression. Rats were given injections of $\mathrm{p} 513$ vector containing the PKG-I CDNA $(0.5 \mu \mathrm{g})$ into the right VTA $(0.6$ $\mu \mathrm{l})$, SNc $(0.6 \mu \mathrm{l})$, or (Pu $(2 \mu \mathrm{l})$ and of $0.5 \mu \mathrm{g}$ of vector lacking a CDNA insert into the left corresponding structure. They were then given injections of $2 \mathrm{nmol}$ of KT5823 or saline and 10 min later injections of $20 \mathrm{nmol}$ of $\mathrm{Br}-\mathrm{cG}$ or saline into the same structures. The injection volumes were $0.5 \mu \mathrm{l}$ for VTA and SNc and $1 \mu \mathrm{l}$ for the CPu. Finally, animals received an intraperitoneal injection of cocaine $(20 \mathrm{mg} / \mathrm{kg}$ ). Rats were killed, and the brains were removed $45 \mathrm{~min}$ after cocaine injection.

Briefly, striata from 15 rats were rapidly dissected and homogenized in chilled phosphate buffer, $\mathrm{pH} 7.5$, containing $320 \mathrm{~mm}$ sucrose and $0.1 \mathrm{~mm}$ EDTA. The crude mitochondrial pellet, obtained by centrifugation at $11,500 \times g$ for $25 \mathrm{~min}$, was washed extensively and resuspended in the same buffer ( $3 \mathrm{ml} / \mathrm{gm}$ tissue). Synaptosomes were isolated on isotonic Ficoll-sucrose discontinuous density gradients. After centrifugation at $53,500 \times g$ for $60 \mathrm{~min}$, material from the $12-16 \%$ Ficoll region was collected, diluted with $3 \mathrm{vol}$ of homogenization buffer, and washed twice with the same buffer. The final pellet obtained by centrifugation at $11,500 \times g$ for $25 \mathrm{~min}$ was resuspended in the same buffer without sucrose $(8 \mathrm{ml} / \mathrm{gm}$ tissue $)$ and taken as the synaptosomal fraction. The synaptosomal membrane fraction was obtained after a freeze-thawing cycle of synaptosomes, followed by centrifugation at $10^{5} \times g$ for 20 min.

In situ hybridization. Animals were given an overdose of pentobarbital $(100 \mathrm{mg} / \mathrm{kg}$, i.p.) and were then perfused transcardially with $50 \mathrm{ml}$ of saline, followed by $1 \%$ formaldehyde in PBS ( $\mathrm{pH} 7.2 ; 250 \mathrm{ml})$. The brains were removed, immersed overnight at $4^{\circ} \mathrm{C}$ in $15 \%$ sucrose, frozen in isopentane at $-40^{\circ} \mathrm{C}$, and then stored at $-80^{\circ} \mathrm{C}$. Coronal tissue sections (10 $\mu \mathrm{m}$ thick) were thaw-mounted onto gelatin-coated glass slides and stored at $-80^{\circ} \mathrm{C}$.

In situ hybridization with an egr-1 riboprobe was performed as described previously (Thiriet et al., 1998). [ ${ }^{35}$ S]-UTP-labeled RNA probe was generated using a subclone containing egr-1 cDNA in pBluescript vector. Sections were delipidated, acetylated, prehybridized for $10 \mathrm{~min}$ at $60^{\circ} \mathrm{C}$ in $50 \%$ formamide/ $1 \times$ SSC $(150 \mathrm{~mm} \mathrm{NaCl}$ and $15 \mathrm{~mm}$ sodium citrate, $\mathrm{pH}$ 7.0), dehydrated, and air dried. Thirty microliters of the labeled probe, diluted to $60,000 \mathrm{dpm} / \mu \mathrm{l}$ with hybridization buffer $(50 \%$ formamide, $4 \times$ SSC, $10 \%$ dextran sulfate, and $10 \mathrm{~mm}$ dithiothreitol), were placed on tissue sections and covered with coverslips. Hybridization was performed overnight at $52^{\circ} \mathrm{C}$. The slides were then washed twice in $50 \%$ formamide, $1 \times \mathrm{SSC}$ at $55^{\circ} \mathrm{C}$ for $1 \mathrm{hr}$, followed by two washes in $2 \times$ SSC. Sections were incubated in $10 \mathrm{~mm}$ Tris- $\mathrm{HCl}$ buffer, $\mathrm{pH}$ 8.0, containing $100 \mathrm{~mm} \mathrm{NaCl}, 1 \mathrm{~mm}$ EDTA, and $6 \cdot 10^{-3} \mathrm{U} / \mathrm{ml}$ RNase A (Merck, Darmstadt, Germany) for $30 \mathrm{~min}$ at $37^{\circ} \mathrm{C}$. The slides were then rinsed, dehydrated, and air dried. The sections were exposed to $\mathrm{x}$-ray film (Biomax-MR; Eastman Kodak, Rochester, NY) for 6 d. For quantitative analysis, densitometry was performed with an image analyzer and Samba software (Alcatel TITN, Massy, France) on comparable areas of brain structures. Measurements were performed on two sections taken at two different levels: the shell part of the NAc and cingulate cortex $(\mathrm{CgCx})$ were measured in sections $1.2 \mathrm{~mm}$ anterior to bregma, and the dorsal and lateral regions of the $\mathrm{CPu}$ were measured in sections $0.3 \mathrm{~mm}$ anterior to bregma. The optical density was measured on four serial sections, and the results were converted into kilobecquerels per gram of tissue, using $\left[{ }^{14} \mathrm{C}\right]$ microscales (Amersham Biosciences, Little Chalfont, UK) for calibration. Statistical analysis was performed with ANOVA, followed by Student-Newman-Keuls multiple comparisons test.

Immunoblotting. For PKG detection, animals were given an overdose of pentobarbital ( $100 \mathrm{mg} / \mathrm{kg}$, i.p.), and striata were dissected and homogenized in 20 mM Tris-HCl buffer, $\mathrm{pH} 7.5$, containing $1 \mathrm{~mm}$ EDTA and 0.1 $\mathrm{mm}$ dithiothreitol. Homogenates were centrifuged at $10^{5} \times g$ for $20 \mathrm{~min}$ 
at $4^{\circ} \mathrm{C}$, and identical amounts of protein, assessed by the Bradford technique (Bradford, 1976), from resulting supernatants were subjected to SDS-PAGE (10\%). The separated proteins were transferred onto nitrocellulose membranes. The resulting blots were blocked in PBS containing $0.2 \%$ casein and $0.1 \%(\mathrm{v} / \mathrm{v})$ Tween 20 , followed by incubation with agitation for 2 $\mathrm{hr}$ at room temperature with primary polyclonal anti-PKG antibody (diluted 1:500; Calbiochem). Blots were washed in $0.1 \%(\mathrm{v} / \mathrm{v})$ Tween 20 in PBS and then incubated with agitation in biotinylated secondary goat antirabbit antibody (1:20,000 dilution) for $30 \mathrm{~min}$ at room temperature, followed by streptavidinalkaline phosphatase conjugation. Antibody binding was detected by chemiluminescence (Tropix, Bedford, MA) with 10-30 min exposure on Kodak Biomax autoradiographic film.

Immunocytochemistry. Sections were prepared as for in situ hybridization experiments, except that $4 \%$ formaldehyde was used for transcardial perfusion and coronal vibratome tissue sections (40 $\mu \mathrm{m}$ thick) were prepared. Immunocytochemistry was performed as described previously (Jouvert et al., 2002). Briefly, brain sections were incubated successively with primary polyclonal anti-PKG antibody (diluted 1:500) and secondary biotinylated donkey antirabbit IgG (1:200 dilution). The sections were then incubated with an avidin-biotin-peroxidase complex (Vectastain ABC kit) and reacted with the chromagen 3,3'-diaminobenzidine tetrahydrochloride (DAB) and $\mathrm{H}_{2} \mathrm{O}_{2}$. For light microscopy, sections were thaw-mounted onto gelatin-coated glass slides, coverslipped with Mowiol, and observed with a microscope (Zeiss, Oberkochen, Germany). For electron microscopy, sections after DAB treatment were fixed for $15 \mathrm{~min}$ in sodium cacodylate-buffered $2 \%$ glutaraldehyde ( $0.125 \mathrm{~m} ; \mathrm{pH} 7.4$ ) at room temperature. Sections were then rinsed in sodium cacodylate buffer and postfixed in $1 \%$ osmium tetroxide in the same buffer for $2 \mathrm{hr}$ at room temperature. Ultrathin sections ( $60 \mathrm{~nm}$ thick) were observed without post-staining at $60 \mathrm{kV}$ with a Hitachi H-7500 transmission electron microscope.

For confocal microscopy, sections obtained as described above (in situ hybridization section) were delipidated, postfixed with $4 \%$ formaldehyde in PBS for $15 \mathrm{~min}$, and incubated in PBS containing 0.5\% bovine serum albumin for $30 \mathrm{~min}$. Slides were then incubated overnight at room temperature with rabbit anti-PKG (diluted 1:500; Calbiochem) together with one of the following primary antibodies: monoclonal anti-tyrosine hydroxylase (diluted 1:1000; Sigma), monoclonal anti-parvalbumin (diluted 1:400; Sigma), or goat choline acetyltransferase (diluted 1:200; Jackson ImmunoResearch, West Grove, PA). After washing, slides were incubated for $1 \mathrm{hr}$ with the corresponding secondary antibody: Alexa 488-labeled anti-rabbit (diluted 1:1000; Molecular Probes, Eugene, OR), Cy3-labeled anti-mouse (diluted 1:800; Jackson ImmunoResearch), or Alexa 568-labeled anti-goat (diluted 1:1000; Molecular Probes). Sequential through-focus images of labeled cells were acquired using a confocal laser scanning microscope (LSM 410 invert; Zeiss) equipped with a $63 \times$ immersion lens. Nonspecific fluorescence was assessed by incubating cells with secondary antibodies alone and measuring the average intensity for each fluorochrome. This value was then subtracted from individual images. Each optical section was scanned eight times to obtain an average image.

PKG assay. PKG activity was measured essentially as described previously (Butt et al., 1994). Activity was estimated as the phosphorylation of the selective peptide substrate LRKVSKQE. Striata were dissected and homogenized in 20 mM Tris-HCl buffer, $\mathrm{pH} 7.5$, containing 1 mM EDTA,
i-VTA

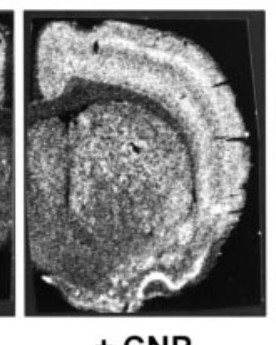

+ CNP
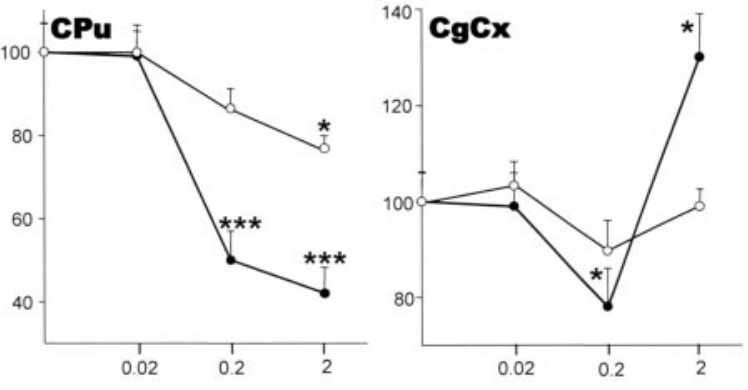

CNP (nmoles)

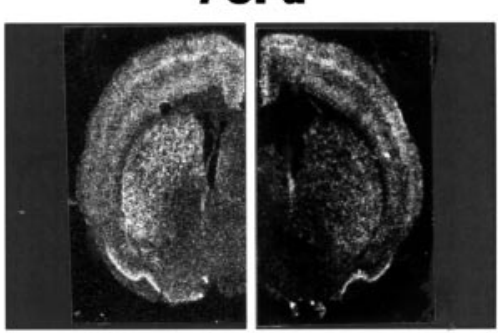

Control
+ CNP
i-CPu

Figure 2. Effect of various doses of CNP on cocaine-induced egr-1 gene expression. $A$, Negative prints of in situ hybridization ( 0.01 , and ${ }^{* * *} p<0.001$ indicate the degree of significance when comparing CNP treatment versus the control group (ANOVA Keuls multiple comparisons test).

$0.1 \mathrm{~mm}$ dithiothreitol, and $10 \%$ glycerol. The homogenate was centrifuged at $10^{5} \times g$ for $20 \mathrm{~min}$ at $4^{\circ} \mathrm{C}$, and PKG activity was assayed in the resulting supernatant. The reaction mixture ( $80 \mu \mathrm{l}$ total volume) contained $20 \mathrm{~mm}$ Tris- $\mathrm{HCl}, \mathrm{pH}$ 7.4, $10 \mathrm{~mm} \mathrm{MgCl}_{2}, 0.5 \mathrm{~mm}$ dithiothreitol, 0.1 $\mathrm{mg} / \mathrm{ml}$ bovine serum albumin, $\left[\gamma^{-}{ }^{32} \mathrm{P}\right] \mathrm{ATP}(16 \mu \mathrm{M}, 100 \mathrm{cpm} / \mathrm{pmol})$, and $15 \mu \mathrm{g}$ of protein extract. Assays were conducted in the presence or absence of $10 \mu \mathrm{M} \mathrm{cGMP}$ at $30^{\circ} \mathrm{C}$ for $10 \mathrm{~min}$ and were terminated by transferring samples onto phosphocellulose P-81 paper (Whatman, Clifton, $\mathrm{NJ}$ ) and washing them in $75 \mathrm{~mm}$ phosphoric acid. Papers were washed in ethanol, then in ether and dried. Radiolabeled peptide was quantitated by liquid scintillation spectrometry.

Locomotor activity. To measure spontaneous locomotor activity, rats were placed individually in a cubic Plexiglas chamber $(46.5 \mathrm{~cm}$ per side) transected by photobeams. After a 120 min habituation session in the chamber, rats that had received bilateral injections of the vector containing PKG-I $\alpha$ cDNA or empty vector and with PKG activators and/or inhibitors into the $\mathrm{CPu}$, as illustrated in Figure 1, were given an intraperitoneal cocaine injection $(20 \mathrm{mg} / \mathrm{kg})$. They were placed in the chamber immediately after cocaine administration, and locomotor activity was measured by counting the number of photobeams crossed over the next 120 min period under normal lighting conditions.

\section{Results}

\section{Effect of CNP injected into DAergic structures}

We investigated the effect on egr-1 mRNA expression of the injection of various doses of CNP directly into the right hemi-VTA or hemi-CPu. Saline solution was injected into the left corresponding structure and used as the control. Rats received an intraperitoneal injection of cocaine $15 \mathrm{~min}$ after microinjection of 
Table 1. Effect of CNP and KT5823 on cocaine-induced egr-1 expression

\begin{tabular}{lllll}
\hline & Dor CPu & Lat CPu & NAc & CgCx \\
\hline Cocaine & $5.8 \pm 0.9$ & $6.0 \pm 1.4$ & $10.7 \pm 0.9$ & $5.3 \pm 1.3$ \\
Cocaine plus CNP & $2.4 \pm 0.8^{* * *}$ & $2.2 \pm 0.9^{* * *}$ & $7.1 \pm 0.6^{* * * *}$ & $7.4 \pm 0.7^{*}$ \\
Cocaine plus CNP plus KT5823 & $6.2 \pm 1.2^{\# \# \#}$ & $6.5 \pm 0.7^{\# \# \#}$ & $8.5 \pm 1.0^{\#}$ & $6.2 \pm 1.1$
\end{tabular}

Data show Egr-1 mRNA expression in comparable areas of the NAc shell, the dorsal (Dor CPu) or lateral (Lat CPu) region of the striatum, and the anterior $\mathrm{Cg} C \mathrm{x}$ from rats given microinjections of $2 \mathrm{nmol}$ of CNP, $2 \mathrm{nmol}$ of KT5823, or vehicle into the hemi-CPu. Fifteen minutes later, rats were given intraperitoneal injections of cocaine $(20 \mathrm{mg} / \mathrm{kg})$ and killed $45 \mathrm{~min}$ afterward. The results are expressed as kilobecquerels per gram of tissue, as means $\pm S D(n=12$ sections from 3 animals). ${ }^{*}$ or ${ }^{\#} p<0.05$ and ${ }^{* * *}$ or ${ }^{\# \# \# p} p<0.001$. Asterisks indicate significance levels when comparing CNP versus the vehicle group; ${ }^{\#}$ indicates significance when comparing CNP plus KT5823 versus CNP treatment (ANOVA, followed by Student-Newman-Keuls multiple comparisons test).

CNP. Figure $2 A$ illustrates egr- 1 mRNA expression in coronal sections at the level of $\mathrm{CPu}$. Forty-five minutes after cocaine injection, egr-1 mRNA was expressed at a very high level in the $\mathrm{CPu}$ and in the frontal and piriform cortices (Fig. $2 \mathrm{~A}$, Control). A significant reduction of this expression was observed in the $\mathrm{CPu}$ when $2 \mathrm{nmol}$ of CNP was injected into the CPu 15 min before cocaine administration (Fig. $2 \mathrm{~A}, \mathrm{CNP}$ ). The effect was much less pronounced when CNP was injected into the VTA. A direct effect of CNP resulting from the diffusion of the peptide into neighboring structures can be excluded, because experiments with biotinylated CNP injected into the $\mathrm{CPu}$ under similar conditions showed that the peptide did not diffuse outside the CPu (see supplemental material, available at www.jneurosci.org).

Quantitative densitometric analysis of egr-1 expression in the shell part of the NAc, the dorsal region of the Cpu, and the anterior $\mathrm{CgCx}$ is shown in Figure 2 B. Data were obtained from in situ autoradiograms of coronal sections of the NAc and CPu of rats injected with various doses of CNP. Whether it was injected into the VTA or into the $\mathrm{CPu}, \mathrm{CNP}$ was found to dose-dependently reduce cocaine-induced egr-1 expression in the NAc. The situation was more complex in the CgCx: $0.2 \mathrm{nmol}$ of CNP injected into the $\mathrm{CPu}$ reduced cocaine-induced egr-1 transcription, but egr-1 mRNA synthesis was found to be increased by $2 \mathrm{nmol}$ of CNP. Injection into the VTA had no effect on gene expression in the $\mathrm{CgCx}$ and only minimally affected egr- 1 expression in the $\mathrm{CPu}$.

Because CNP signals by raising intracellular cGMP and by activating PKG, we checked whether the effect of 2 nmol of CNP could be reversed by a selective PKG inhibitor, KT5823. Table 1 shows that injection of $2 \mathrm{nmol}$ of KT5823 $10 \mathrm{~min}$ before CNP into the same $\mathrm{CPu}$ site was found to completely reverse the inhibitory effect of CNP on cocaine-induced egr-1 mRNA expression in the $\mathrm{CPu}$. The effect was less pronounced in the NAc. The stimulatory effect of CNP found in the $\mathrm{CgCx}$ was also reversed by the inhibitor, but this was not statistically significant. This result suggests that the cGMP transduction pathway is involved in the mode of action of CNP.

Effect of PKG activation on cocaine-induced egr-1 expression We subsequently investigated the effect of PKG activation on cocaine-induced egr-1 expression in rat striatum. In agreement with data from the literature, we found that the kinase was localized in synaptosomes prepared from rat striata, by using the Western blot technique and by measuring PKG enzymatic activity (data not shown). Using an anti-PKG-I antibody and electron microscopy, PKG-I was found associated with postsynaptic densities and, to a lesser extent, at presynaptic terminals (data not shown).

The effect of PKG activation on cocaine-induced egr-1 mRNA expression was studied by injecting $\mathrm{Br}-\mathrm{cG}$ (20 nmol), a cellpermeant analog of cGMP, into the right hemi-CPu, hemi-VTA, or hemi-substantia nigra compacta $(\mathrm{SNc})$. The left correspond-

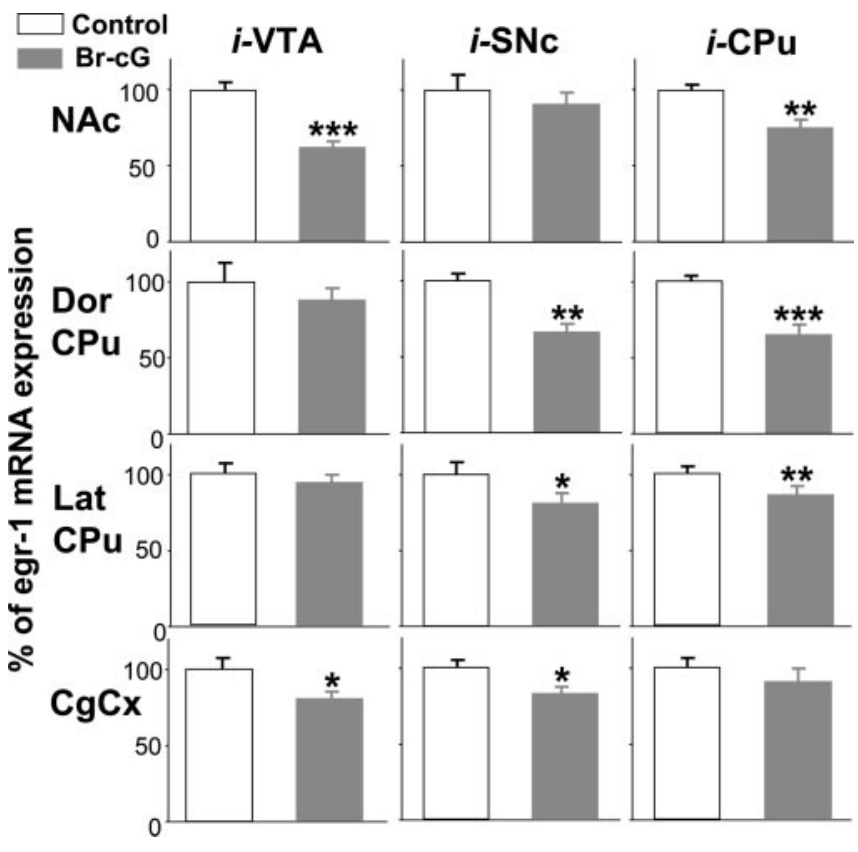

Figure 3. Effect of $\mathrm{Br}-\mathrm{cG}$ injection on cocaine-induced egr-1 gene expression. Densitometric analysis of the effect of $\mathrm{Br}$ - $\mathrm{CG}$ injection on cocaine-induced egr-1 gene expression. Comparable areas of the Nac shell, the dorsal (Dor CPu) or lateral (Lat $\mathrm{CPu}$ ) region of the striatum, and the anterior $\mathrm{Cg} \mathrm{C}$ were quantified from in situ autoradiograms of sections from rats given injections of $20 \mathrm{nmol}$ of Br-cG into the right VTA $(0.5 \mu \mathrm{l}), \mathrm{SNc}(0.5 \mu \mathrm{l})$, or CPu $(2 \mu \mathrm{l})$ or injection of vehicle into the left corresponding structure (Control). Fifteen minutes later, rats were given intraperitoneal injections of cocaine $(20 \mathrm{mg} / \mathrm{kg})$ and killed after $45 \mathrm{~min}$. Results are expressed as a percentage of control, as means \pm SEM ( $n=12$ sections from 3 animals). ${ }^{*} p<0.05,{ }^{* *} p<$ 0.01 , and ${ }^{* * *} p<0.001$ indicate significance when comparing $\mathrm{Br}-\mathrm{cG}$ treatment versus the corresponding control group (ANOVA, followed by Student-Newman-Keuls multiple comparisons test).

ing structure was injected with saline and was used as control. Rats were given an intraperitoneal cocaine injection 15 min after the $\mathrm{Br}-\mathrm{cG}$ microinjection. Quantitative densitometric analysis of egr-1 expression in the NAc shell, in the dorsal (Dor $\mathrm{CPu}$ ) or lateral $(\mathrm{Lat} \mathrm{CPu})$ region of the striatum, and in the $\mathrm{CgCx}$ is shown in Figure 3. Data were obtained from in situ autoradiograms of coronal sections taken at the level of NAc and $\mathrm{CPu}$. When $\mathrm{Br}-\mathrm{cG}$ was microinjected into the VTA, there was a considerable $(\sim 35 \%)$ decrease in cocaine-induced egr-1 expression in the NAc and a lesser decrease in the $\mathrm{CgCx}$. No statistically significant reduction was found in the $\mathrm{CPu}$. When injected into the $\mathrm{SNc}, \mathrm{Br}-\mathrm{cG}$ caused a significant reduction of the early gene expression in all regions, except the NAc, and when injected into the $\mathrm{CPu}$, it reduced egr-1 transcription in all structures, except the CgCx.

\section{Characterization of overexpressed PKG}

To further confirm that PKG activation can modify cocaineinduced transcription, we overexpressed the kinase either in the mesencephalon or in the $\mathrm{CPu}$, by injecting a plasmid vector containing the human PKG-I $\alpha$ cDNA, using the PEI delivery system. We first verified that the delivery protocol used produced an active protein. The Western blot using an anti-PKG-I antibody (Fig. 4A) shows that immunoreactivity in the striatum was highest $24 \mathrm{hr}$ after plasmid delivery in the right hemi- $\mathrm{CPu}$, compared with the left hemi- $\mathrm{CPu}$, which had received an injection of the plasmid lacking an insert. This suggests that the PKG cDNA was indeed translated into a protein with the expected $M_{\mathrm{r}}$ of 75,000. The enzymatic activity of the overexpressed protein was then verified by measuring PKG activity toward phosphorylation of a 


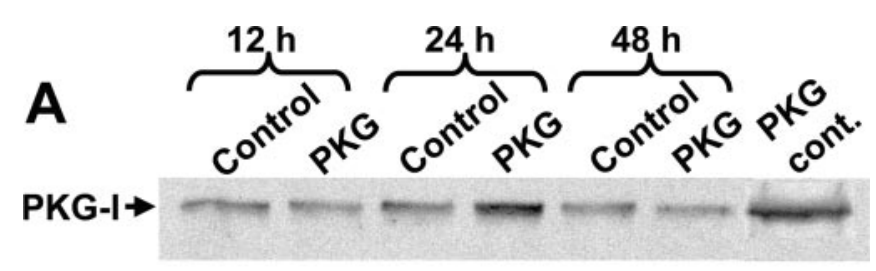

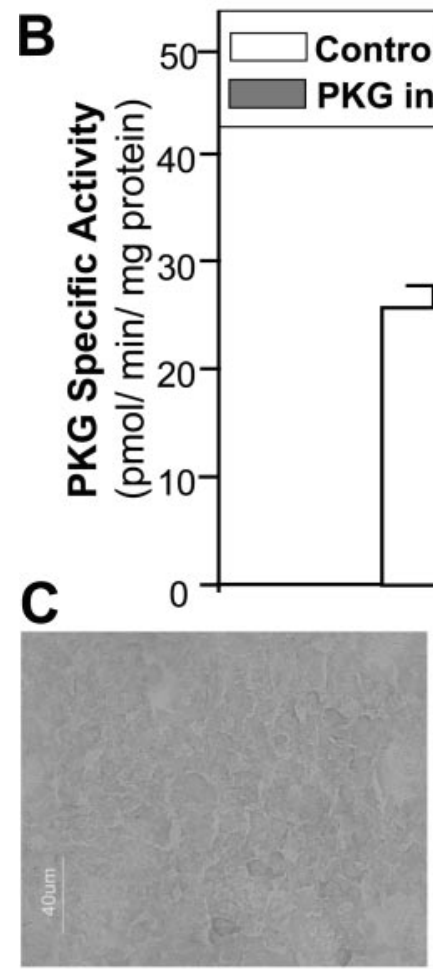

Control

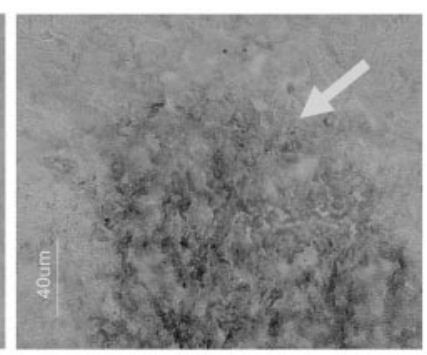

PKG injected
Figure 4. Characterization of overexpressed PKG in rat striatum. Plasmid p513 $(0.5 \mu \mathrm{g}, 2$ $\mu l)$ containing the PKG-I $\alpha$ CDNA (PKG) or empty vector (Control) was microinjected into the right and left $\mathrm{CPu}$, respectively. $A$, Western blot analysis using polyclonal anti-PKG-I antibody showing PKG-I expression as a 75,000 protein, in striata prepared at various times after plasmid injection. PKG cont., Reactivity of pure PKG from a commercial source. B, PKG-specific activity measured in the hemistriata $24 \mathrm{hr}$ after plasmid injection. C, Immunohistochemical detection of PKG in the CPu $24 \mathrm{hr}$ after plasmid injection. Sections were incubated in anti-PKG antibody, then with a secondary biotinylated antibody, and PKG was revealed with streptavidin-peroxidase complex, followed by staining with diaminobenzidine and $\mathrm{H}_{2} \mathrm{O}_{2}$. The arrow indicates the PKG overexpression sphere. Scale bar, $40 \mu \mathrm{m}$.

selective peptide substrate. Figure $4 B$ shows that $24 \mathrm{hr}$ after the plasmid injection, PKG activity was increased approximately twofold in the hemi- $\mathrm{CPu}$ injected with the plasmid compared with the control side, indicating that our injection protocol gave rise to the synthesis of an enzymatically active kinase.

An immunohistochemical study was performed to detect PKG expression in the striatum around the injection site (Fig. $4 C)$. In the $\mathrm{CPu}$ injected with the empty vector, PKGimmunoreactive cells were evenly distributed throughout the structure; in contrast, a dramatic increase in the number of cells that intensely express PKG was observed around the point where the plasmid containing PKG-I $\alpha$ cDNA was injected (Fig. $4 C$ ). The volume of the PKG overexpression sphere was estimated to be $\sim 2 \times 10^{7} \mu \mathrm{m}^{3}$. A similar effect was observed when PKG was injected into the VTA or the SNc (data not shown).

We next characterized the cells that overexpressed PKG using double-labeling techniques. For this, we studied only labeling inside the overexpression sphere. Surprisingly, double labeling
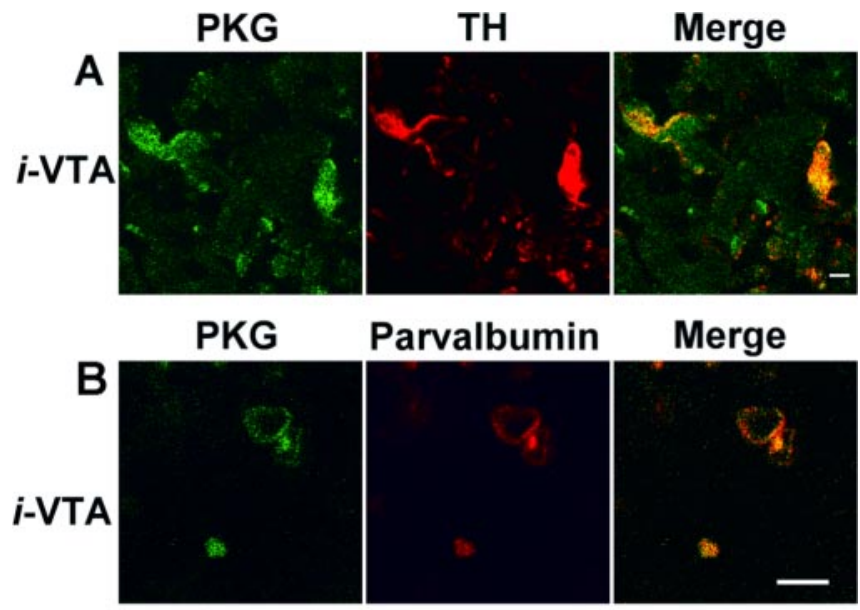

Merge
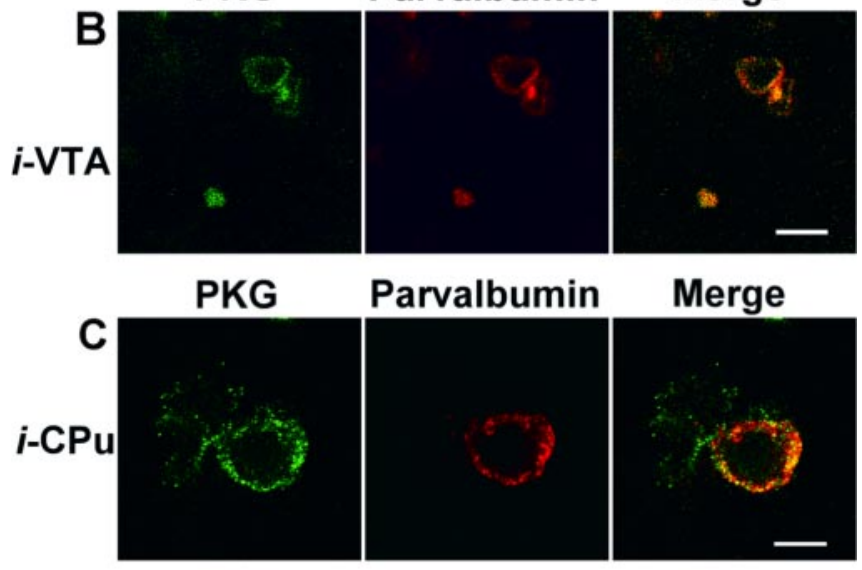

Parvalbumin
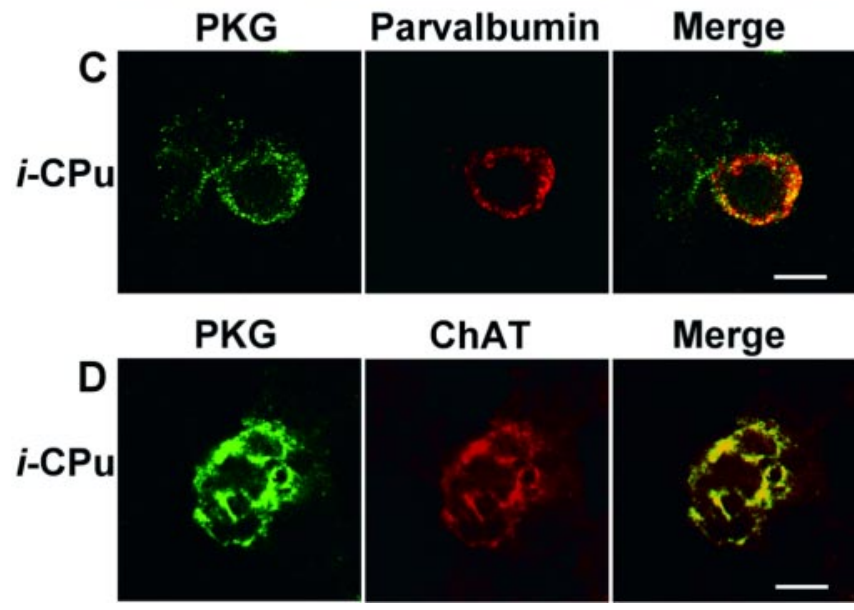

Merge

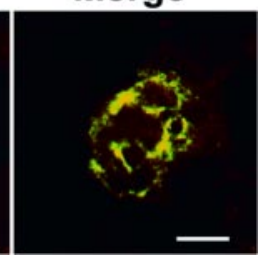

Figure 5. Double labeling for PKG and neuronal markers after PKG plasmid injection. Immunofluorescence confocal micrographs of brain cells transfected with the $\mathrm{p} 513$ vector containing PKG-I $\alpha$ CDNA. Only cells inside the overexpression sphere were considered. $A$, Plasmid was injected into the VTA; brain sections were incubated with antibodies against PKG and against tyrosine hydroxylase (TH). Secondary labeled antibodies against PKG (Alexa Fluor 488; green) and TH (Cy3; red) were used. $B$, Plasmid was injected into the VTA; sections were incubated with antibodies against PKG and against parvalbumin. The secondary labeled antibody against PKG was as above. An antibody labeled with Alexa Fluor 568 (red) against parvalbumin was used. C, Plasmid was injected into the $\mathrm{CPu}$; sections were incubated with antibodies against PKG and against parvalbumin. The secondary labeled antibodies were as in B. D, Plasmid was injected into the $\mathrm{CPu}$; sections were incubated with antibodies against PKG and choline acetyltransferase (ChAT). The secondary antibodies were as in $B$. Scale bars: $A, B, 10 \mu \mathrm{m} ; C, D, 5 \mu \mathrm{m}$.

for PKG and GFAP (glial fibrilliary acidic protein) revealed that the kinase was not expressed in astrocytes, whatever the PKG injection site (data not shown). In contrast, when the PKG plasmid was injected into the VTA, it was found to be unambiguously expressed in DAergic neurons, because PKG was clearly localized in tyrosine hydroxylase-positive neurons (Fig. 5A). A few GABAergic neurons also expressed PKG (Fig. $5 B$ ), as shown by the coexpression of PKG and parvalbumin, a marker of GABAergic interneurons, and, to a lesser extent, long-axon cells (Celio, 1990). As expected, PKG was not expressed in DAergic neurons when the PKG plasmid was injected into the $\mathrm{CPu}$ (data not shown). In the latter case, PKG was found to be coexpressed in striatal neurons that also express parvalbumin (Fig. 5C) or those expressing choline acetyltransferase, a marker of cholinergic neurons (Fig. 5D). This suggests that microinjection of the PKG cDNA vector into the striatum produced the overexpression of the kinase in medium spiny GABAergic neurons and in cholinergic and GABAergic interneurons. 


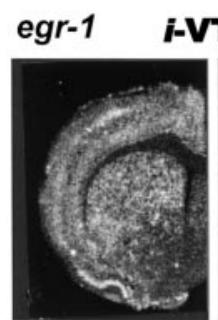

$+\mathrm{Br}-\mathrm{cG}$

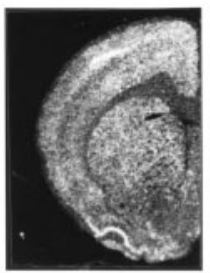

+ PKG

$+\mathrm{Br}-\mathrm{cG}$

$+\mathrm{KT} 5823$

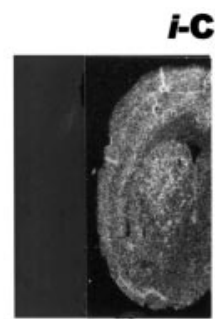

$+\mathrm{Br}-\mathrm{cG}$

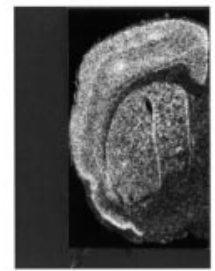

+ PKG

$+\mathrm{Br}-\mathrm{cG}$

+ KT5823

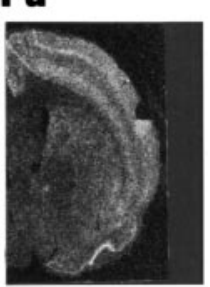

+ PKG

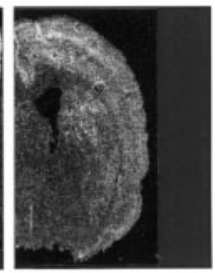

+ PKG

$+\mathrm{Br}-\mathrm{cG}$
+ PKG

$+\mathrm{Br}-\mathrm{cG}$

Figure 6. Egr-1 gene expression in response to cocaine and PKG activator or inhibitor. Negative prints of in situ hybridization autoradiograms showing mRNA expression of egr-1 in rat hemibrain coronal sections taken as described in the legend to Figure $2 A$. Rats were given microinjections of the various compounds into the VTA or CPu with $0.5 \mu \mathrm{g}$ of plasmid PKG, 20 $\mathrm{nmol}$ of $\mathrm{Br}-\mathrm{CG}$, and $2 \mathrm{nmol}$ of $\mathrm{KT} 5823$, according to the injection schedule shown in Figure 1. They were given intraperitoneal injections of $20 \mathrm{mg} / \mathrm{kg}$ cocaine and killed $45 \mathrm{~min}$ after cocaine injection. The corresponding control is shown in Figure $2 \mathrm{~A}$.

\section{Effect of PKG overexpression on cocaine-induced} egr-1 expression

The effect of PKG overexpression on cocaine-induced egr-1 mRNA expression was studied after additional injection of the PKG activator Br-cG or the selective inhibitor KT5823 into the same site, according to the protocol described in Figure 1. Figure 6 illustrates the egr-1 mRNA expression observed 45 min after cocaine administration, in coronal sections taken at the level of the $\mathrm{CPu}$. When injected into the $\mathrm{CPu}, \mathrm{Br}-\mathrm{cG}$ was found to reduce cocaine-induced egr-1 expression in the $\mathrm{CPu}$ (see corresponding control in Fig. 2A). This effect was much less pronounced when $\mathrm{Br}-\mathrm{cG}$ was injected into the VTA, as was observed with CNP injections. After injection of the plasmid into the $\mathrm{CPu}$, exogenous kinase was also found to reduce cocaine-induced egr-1 expression in the striatum to a greater extent than when the plasmid was injected into the VTA. The reduction was enhanced when the kinase was activated by the subsequent injection of the cellpermeant cGMP analog Br-cG. In addition, injection of the kinase inhibitor before the activation of the kinase was found to result in a much less pronounced inhibition (Fig. 6). Injection of a glucose vehicle solution did not produce any significant effect by itself (data not shown).

Quantitative densitometric analysis of egr-1 expression in the $\mathrm{NAc}$ shell, in the dorsal (Dor $\mathrm{CPu}$ ) or lateral (Lat $\mathrm{CPu}$ ) region of striatum, and in the $\mathrm{CgCx}$ is shown in Figure 7. Data were obtained from in situ autoradiograms of coronal sections taken at the level of the NAc and the CPu. Overexpression of PKG into the VTA was found to reduce cocaine-induced egr-1 expression in the NAc and the $\mathrm{CgCx}$, but not in the $\mathrm{CPu}$. When injected into the $\mathrm{CPu}$, it reduced gene expression in the four structures examined; this was also the case, except for the NAc, when PKG was injected into the SNc. Activation of exogenously added PKG by $\mathrm{Br}-\mathrm{cG}$ produced a much greater inhibition of gene transcription that was statistically significant in all the structures examined,

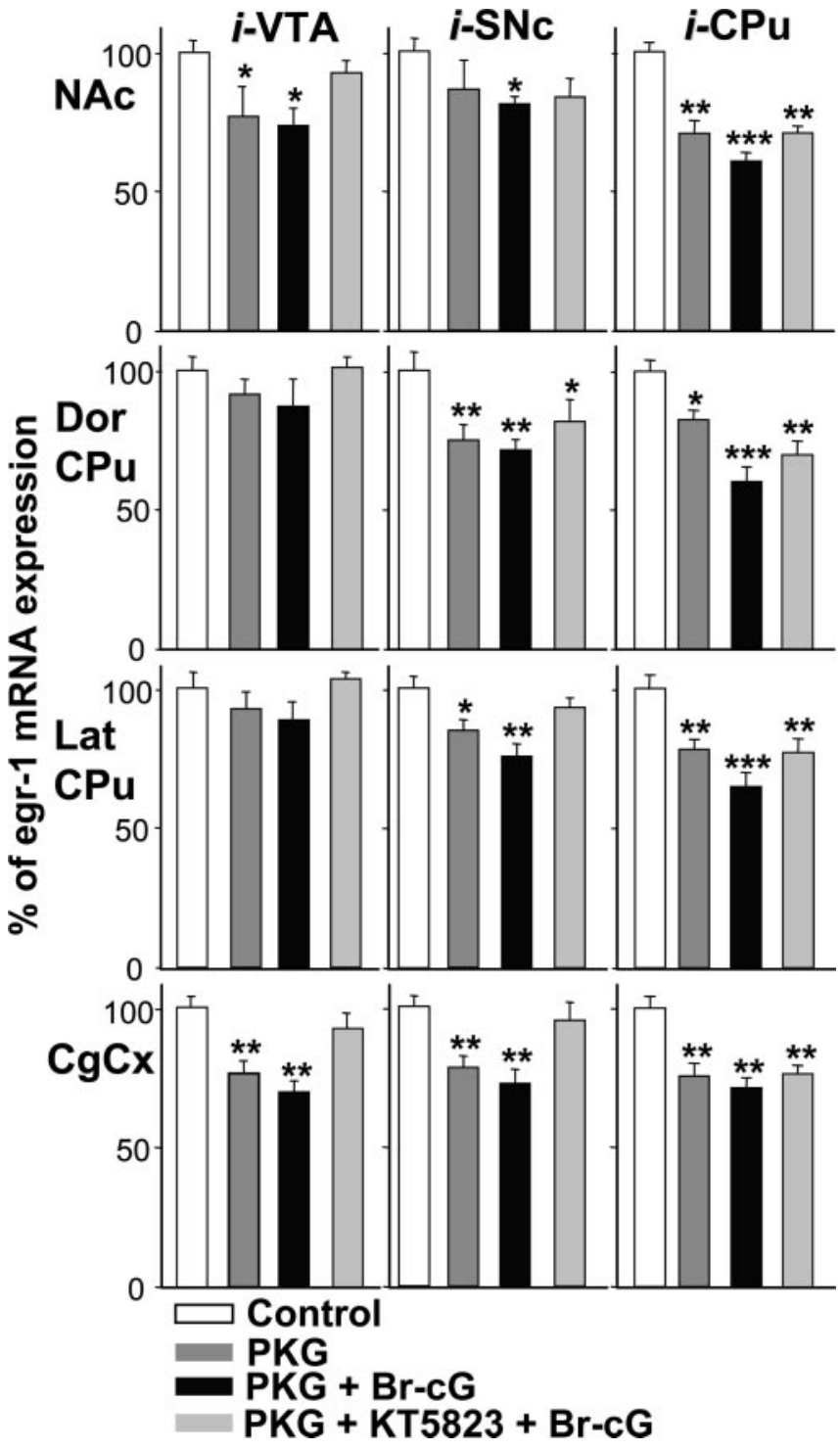

Figure 7. Densitometric analysis of the effect of PKG overexpression on cocaine-induced egr-1 mRNA expression. Comparable areas of the Nac shell, the dorsal (Dor CPu) or lateral (Lat $\mathrm{CPu}$ ) region of the striatum, and the anterior $\mathrm{C} \mathrm{C} \mathrm{x}$ were quantitated from in situ autoradiograms of sections from rats given injections of $0.5 \mu \mathrm{g}$ of plasmid $\mathrm{p} 513$ containing the PKG-I $\alpha$ CDNA (PKG), then with $20 \mathrm{nmol}$ of $\mathrm{Br}-\mathrm{cG}$ and $2 \mathrm{nmol}$ of KT5823 into the right VTA $(0.5 \mu \mathrm{l})$, SNc $(2 \mu \mathrm{l})$ or $\mathrm{CPu}(2 \mu \mathrm{l})$, as indicated, according to the injection protocol shown in Figure 1. Rats were given injections of the plasmid lacking an insert and injection of the various vehicle solutions into the left corresponding structure (Control). They were killed 45 min after cocaine injection. Results are expressed as a percentage of control, as means \pm SEM ( $n=12$ sections from 3 animals). ${ }^{*} p<0.05,{ }^{* *} p<0.01$, and ${ }^{* * *} p<0.001$ indicate significance levels when comparing treated versus the control group (ANOVA, followed by Student-Newman-Keuls multiple comparisons test).

except for the $\mathrm{CPu}$ when PKG was overexpressed in the VTA. This inhibition was highest when PKG was injected into the $\mathrm{CPu}$. Injection of the PKG inhibitor KT5823 was found to reverse the inhibition caused by Br-cG. Together, our results very strongly suggest that the effect of PKG plasmid injection on gene expression is triggered by the enzymatic activity of the additional kinase.

\section{Effect of PKG overexpression on cocaine-induced} locomotor activity

Finally, we investigated whether PKG overexpression affected a cocaine-induced behavior, such as the increase in spontaneous 


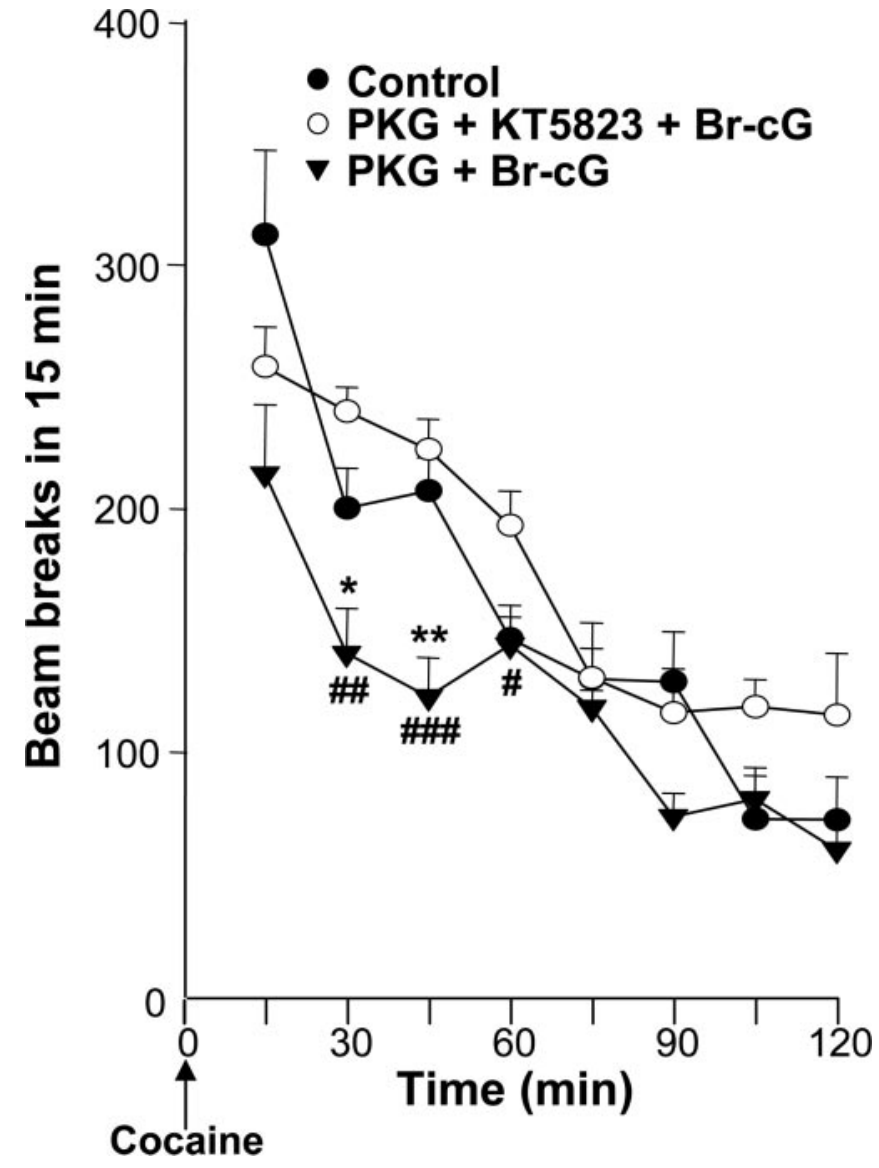

Figure 8. Effect of PKG overexpression on cocaine-induced locomotor activity. Three groups of rats were given bilateral microinjections in the (Pu with PKG-I cDNA plasmid $(0.5 \mu \mathrm{g}, 2 \mu \mathrm{l})$ and $20 \mathrm{nmol}$ of $\mathrm{Br}-\mathrm{CG}$ (PKG $+\mathrm{Br}-\mathrm{CG}$ group); and $0.5 \mu \mathrm{g}$ of plasmid, $2 \mathrm{nmol}$ of KT5823, and 20 nmol of Br-cG (PKG + KT5823 + Br-cG group); or empty plasmid and saline (Control). Each group of animals received an injection of cocaine $(20 \mathrm{mg} / \mathrm{kg})$, according to the protocol shown in Figure 1. Each point represents the mean $\pm \operatorname{SEM}(n=5)$ of beam breaks. ${ }^{*}$ or ${ }^{\#} p<0.05$; ${ }^{\# \#} p<0.01$ and ${ }^{* * *}$ or ${ }^{\# \#} p<0.001$. ${ }^{*}$ indicates significance when comparing treated versus the control group; " indicates significance when comparing PKG plus KT5823 plus Br-cG versus other treatments (ANOVA, followed by Student-Newman-Keuls multiple comparisons test).

locomotion. No significant difference was observed in locomotor activity during a $2 \mathrm{hr}$ habituation period between three groups of rats injected bilaterally with plasmid containing PKG-I cDNA or empty vector into the $\mathrm{CPu}$ (data not shown). Rats were then injected with the PKG activator Br-cG or inhibitor KT5823, followed by intraperitoneal cocaine injection, according to the injection schedule described in Figure 1. Activation of overexpressed PKG resulted in a significant reduction in locomotor activity during the $30-45$ min period after cocaine administration (Fig. 8). Again, the effect was reversed (significantly during the 30-60 min period) by injection of the selective kinase inhibitor into the same site.

\section{Discussion}

\section{CNP reduces cocaine-induced egr-1 expression}

The present study demonstrates that microinjection of CNP into brain structures containing either DAergic neurons or their projection fields reduced the cocaine-induced egr-1 expression in rat forebrain. In addition, the present data show that the cGMP signaling pathway is involved, because activation or overexpression of PKG-I similarly inhibited cocaine-induced egr-1 expression and locomotor activity. The study extends and broadens results from two previous reports that showed that intracerebroventricular injection of CNP and also the NO generator sodium nitroprusside regulate several cocaine-induced effects, such as gene transcription, extracellular DA rise, or locomotor activity (Thiriet et al., 2001, 2002). CNP acts by stimulation of the GC-B receptor, which is widely expressed in rat brain. GC-Bimmunoreactive cells were found to be localized in the mesencephalon and also in regions innervated by DAergic projections such as the $\mathrm{CPu}, \mathrm{Nac}$, and $\mathrm{CgCx}$ (Thiriet et al., 2001). It is worth noting that GC-B was found to be expressed in DAergic neurons themselves, as demonstrated by double-immunolabeling confocal microscopy of the VTA for GC-B and tyrosine hydroxylase (data not shown).

Cocaine-induced egr-1 mRNA transcription in the NAc was reduced whether CNP was injected into the mesencephalon or into the $\mathrm{CPu}$. The effect was less pronounced in the $\mathrm{CPu}$ when CNP was injected into the VTA. It is known that IEG expression in the striatum occurs in GABAergic medium spiny neurons that express the DA D1 receptor (Mailleux et al., 1992; Daunais and McGinty, 1996; Drago et al., 1996): the stimulation of this receptor results in a rise in intracellular cAMP, which could then produce the cocaine-induced IEG transcription, by activating a transcription factor of the CREB (cAMP response element-binding protein) family (Konradi et al., 1994; Andersson et al., 2001). The situation appears to be more complex in the $\mathrm{CgCx}$ because injection of CNP into the CPu produced a biphasic effect: whereas the lower CNP dosage reduced cocaine-induced egr-1 transcription, injection of $2 \mathrm{nmol}$ of $\mathrm{CNP}$ into the $\mathrm{CPu}$ caused an increase in cortical gene expression, suggesting that an additional indirect stimulation occurs in neurons from the frontal cortex. Such an effect had already been observed when CNP was injected intracerebroventricularly (Thiriet et al., 2001). This contrasting observation may in part be attributable to the fact that in the frontal cortex cocaine-induced increase of extracellular DA results mostly from the blockade of the noradrenaline transporter, as shown by the concomitant increase of cortical noradrenaline and DA (Tanda et al., 1997).

Because CNP reduced cocaine-induced egr-1 transcription and the extracellular DA rise in the striatum, it is tempting to suggest that CNP acts by inhibiting DA release in the DAergic projection fields. This hypothesis is supported by previous reports showing that natriuretic peptides inhibit various secretory responses such as renin, aldosterone, catecholamine, or luteinizing hormone-releasing hormone secretion (Samson et al., 1993; Babinski et al., 1995; Rodriguez-Pascual et al., 1996; Kanwal et al., 1997). Interestingly, NO, which activates sGC, also alters the release of several neurotransmitters including DA and 5-HT in the striatum (Guevara-Guzman et al., 1994).

\section{PKG activation, or overexpression, reduces egr-1 expression} induced by cocaine

The effects of the intracellular rise in cGMP generated by GC-B stimulation are primarily mediated by the activation of PKGs. The present data confirm that enzymatically active PKG-I is present in rat striatum, in agreement with previous reports demonstrating that the several components of the cGMP signaling pathway, including PKG, are predominantly localized in neurons characterized either as medium spiny neurons of the striatum (Ariano, 1983), or as striatonigral neurons (Walaas et al., 1989). Moreover, the cGMP pathway components have been described as confined to the postsynaptic region of asymmetrical terminal boutons, derived from afferents from the neocortex, thalamus, 
and, interestingly, the SN (Ariano, 1983). PKG has also been shown to be present in the mesencephalon (Walaas et al., 1989; Bonkale et al., 1997).

When PKG was activated by injection of the cell-permeant 8-bromo-cGMP into the structures containing it, cocaineinduced egr-1 expression was reduced in a very similar way to that observed when CNP was injected into those structures. Gene transcription was reduced in several DA projection fields when PKG was activated in the mesencephalon, with the notable exceptions that no effect was found in the NAc when PKG was activated in the SNc, or in the CPu when PKG was activated in the VTA, in accordance with the known anatomy of DAergic pathways. Only striatal neurons were affected when PKG was activated in the $\mathrm{CPu}$. The results suggest that CNP reduces cocaine-induced egr-1 expression by activating PKG.

To further confirm that PKG could play a role in controlling the activity of DAergic neurons, we injected a plasmid containing PKG-I $\alpha$ cDNA into either the mesencephalon or the CPu, using the PEI delivery system. Immunological and enzymatic studies revealed that the injection protocol used enhanced PKG protein expression $24 \mathrm{hr}$ after the injection. Cocaine-induced egr-1 expression was reduced by $\mathrm{PKG}$ overexpression without injection of permeant cGMP analogs or without stimulation of the cGMP pathway, suggesting that transfected PKG was partially active under basal conditions. Similar results were obtained when PKG is overexpressed in PC12 cells or when high levels of enzyme are present in in vitro assays (Esteve et al., 2001). Alternatively, the apparent "spontaneous" activity of transfected kinase may be attributable to significant activation by endogenous cGMP. When the transfected kinase was activated by $\mathrm{Br}-\mathrm{cG}$, gene expression was further reduced and was statistically significant in all the structures considered, with the exception of the $\mathrm{CPu}$ when overexpressed PKG was activated in the VTA. Moreover, the effect was partially abolished by previous injection of a selective PKG inhibitor. Together, these results demonstrate that enhanced PKG activity was able to significantly reduce the egr-1 gene transcription elicited by cocaine. The locomotor behavior of rats in which PKG was overexpressed in the right hemimesencephalon further argues that the kinase regulates DA release: these rats showed counterclockwise rotational behavior after cocaine injection, which mimics the characteristics of a rat model of Parkinson's disease consisting of the selective unilateral nigrostriatal DAergic lesion and injection of apomorphine (Perese et al., 1989).

\section{Mechanism of action of PKG}

PKG activation in response to cGMP accumulation has been shown to modulate presynaptic activity in various situations, including long-term potentiation (Zhuo et al., 1994). Reduced neurotransmitter release may result from the direct phosphorylation by PKG of L-type (Hell et al., 1993) or N-type (Hell et al., 1994) $\mathrm{Ca}^{2+}$ channels, from PKG-dependent dephosphorylation of $\mathrm{Ca}^{2+}$-activated and voltage-activated $\mathrm{K}^{+}$channels (White et al., 1993 ) or from downregulation of $\mathrm{Ca}^{2+}$ release from inositol triphosphate-sensitive stores (Ruth et al., 1993).

However, reduced DA release in the striatum may be the consequence of a decreased firing of DAergic neurons, rather than through a direct presynaptic effect on $\mathrm{Ca}^{2+}$ homeostasis. In this context, it is noteworthy that striatal NO tone has been shown to regulate basal activity as well as responsiveness of DAergic neurons to cortical and striatal inputs (West and Grace, 2000). The control involves the regulation of GABA release from striatonigral projections. This mechanism is therefore likely to occur when PKG is activated or overexpressed in the CPu. PKG has been shown to promote the phosphorylation of DARPP-32 (DAand cAMP-regulated phosphoprotein) (Tsou et al., 1993), which is expressed in striatal neurons receiving DAergic input (Ouimet et al., 1984). Phospho-DARPP-32 plays a central role in regulating the efficacy of DAergic neurotransmission by inhibiting the activity of protein phosphatase type-1, thus modifying the phosphorylation state and activity of a series of proteins. The fact that phospho-DARPP-32 negatively regulates DAergic neurons via GABA release from striatonigral neurons is validated in mice lacking DARPP-32, which show a reduced behavioral response to cocaine and amphetamine (Fienberg et al., 1998).

\section{Behavioral consequences}

The importance of the inhibition of DA-induced gene transcription by stimulating the cGMP-PKG pathway is illustrated by current data demonstrating that PKG overexpression controls behavioral effects of cocaine, such as spontaneous locomotor activation. The effects produced by the cGMP signaling pathway may modulate drug-induced neural plasticity leading to behavioral alterations. Inhibition of NO synthase has been shown previously to prolong the rewarding effect of cocaine in a selfadministered cocaine protocol (Pudiak and Bozarth, 2002), suggesting that under basal conditions, NO reduces the effect of cocaine. Because a hyperactive midbrain DA system is characteristic of a drug-prone phenotype (Marinelli and White, 2000), the reduced DA release and gene transcription in striatal target neurons observed in response to CNP suggests that the neuropeptide would be able to reduce cocaine self-administration. The involvement of NO in cocaine dependence and in the complex process associated with relapse has been postulated recently (Orsini et al., 2002). Furthermore, the cGMP signaling pathway has been found to be involved in various mechanisms underlying synaptic plasticity (Telegdy et al., 1999; Calabresi et al., 2000).

In summary, the present data demonstrate that activation of the cGMP pathway inhibits cocaine-induced egr-1 expression and locomotor activation. Thus, the natriuretic peptide CNP and, more importantly, NO, both of which use the cGMPsignaling pathway, represent potential regulators of cocainerelated behavioral effects.

\section{References}

Andersson M, Konradi C, Cenci MA (2001) cAMP response elementbinding protein is required for dopamine-dependent gene expression in the intact but not the dopamine-denervated striatum. J Neurosci 21:9930-9943.

Ariano MA (1983) Distribution of components of the guanosine $3^{\prime}, 5^{\prime}$ phosphate system in rat caudate-putamen. Neuroscience 10:707-723.

Babinski K, Haddad P, Vallerand D, McNicoll N, de Lean A, Ong H (1995) Natriuretic peptides inhibit nicotine-induced whole-cell currents and catecholamine secretion in bovine chromaffin cells: evidence for the involvement of the atrial natriuretic factor R2 receptors. J Neurochem 64:1080-1087.

Bhat RV, Baraban JM (1993) Activation of transcription factor genes in striatum by cocaine: role of both serotonin and dopamine systems. J Pharmacol Exp Ther 267:496-505.

Bonkale WL, Cowburn RF, Winblad B, Fastbom J (1997) Autoradiographic characterization of $\left[{ }^{3} \mathrm{H}\right] \mathrm{cGMP}$ binding sites in the rat brain. Brain Res 763:1-13.

Bradford MM (1976) A rapid and sensitive method for the quantitation of microgram quantities of protein utilizing the principle of protein-dye binding. Anal Biochem 72:248-254.

Bredt DS, Snyder SH (1990) Isolation of nitric oxide synthetase, a calmodulin-requiring enzyme. Proc Natl Acad Sci USA 87:682-685.

Butt E, Abel K, Krieger M, Palm D, Hoppe V, Hoppe J, Walter U (1994) cAMP-and cGMP-dependent protein kinase phosphorylation sites of the 
focal adhesion vasodilator-stimulated phosphoprotein (Vasp) in vitro and in intact human platelets. J Biol Chem 269:14509-14517.

Calabresi P, Gubellini P, Centonze D, Picconi B, Bernardi G, Chergui K, Svenningsson P, Fienberg AA, Greengard P (2000) Dopamine and cAMP-regulated phosphoprotein $32 \mathrm{kDa}$ controls both striatal long-term depression and long-term potentiation, opposing forms of synaptic plasticity. J Neurosci 20:8443-8451.

Celio MR (1990) Calbindin D-28k and parvalbumin in the rat nervous system. Neuroscience 35:375-475.

Daunais JB, McGinty JF (1996) The effects of D1 or D2 dopamine receptor blockade on zif/268 and preprodynorphin gene expression in rat forebrain following a short-term cocaine binge. Mol Brain Res 35:237-248.

De Camilli P, Miller PE, Levitt P, Walter U, Greengard P (1984) Anatomy of cerebellar Purkinje cells in the rat determined by a specific immunohistochemical marker. Neuroscience 11:761-817.

de Vente J, Asan E, Gambaryan S, Markerink-van Ittersum M, Axer H, Gallatz K, Lohmann SM, Palkovits M (2001) Localization of cGMP-dependent protein kinase type II in rat brain. Neuroscience 108:27-49.

Di Chiara G, Imperato A (1988) Drugs abused by humans preferentially increase synaptic dopamine concentrations in the mesolimbic system of freely moving rats. Proc Natl Acad Sci USA 85:5274-5278.

Drago J, Gerfen CR, Westphal H, Steiner H (1996) D1 dopamine receptordeficient mouse: cocaine-induced regulation of immediate early gene and substance $\mathrm{P}$ expression in the striatum. Neuroscience 74:813-823.

Esteve L, Lutz P, Thiriet N, Revel M, Aunis D, Zwiller J (2001) Cyclic GMPdependent protein kinase potentiates serotonin-induced Egr-1 binding activity in PC12 cells. Cell Signal 13:425-432.

Fienberg AA, Hiroi N, Mermelstein PG, Song WJ, Snyder GL, Nishi A, Cheramy A, O'Callaghan JP, Miller DB, Cole DG, Corbett R, Haile CN, Cooper DC, Onn SP, Grace AA, Ouimet CC, White FJ, Hyman SE, Surmeier DJ, Girault JA, Nestler EJ, Greengard P (1998) DARPP-32: regulator of the efficacy of dopaminergic neurotransmission. Science 281:838-842.

Garbers DL (1992) Guanylyl cyclase receptors and their endocrine, paracrine and autocrine ligands. Cell 71:1-4.

Guevara-Guzman R, Emson PC, Kendrick KM (1994) Modulation of in vivo striatal transmitter release by nitric oxide and cyclic GMP. J Neurochem 62:807-810.

Hell JW, Yokoyama CT, Wong ST, Warner C, Snutch TP, Catterall WA (1993) Differential phosphorylation of two size forms of the neuronal class C L-type calcium channel alpha 1 subunit. J Biol Chem 268:19451-19457.

Hell JW, Appleyard SM, Yokoyama CT, Warner C, Catterall WA (1994) Differential phosphorylation of two size forms of the N-type calcium channel alpha 1 subunit which have different $\mathrm{COOH}$ termini. J Biol Chem 269:7390-7396.

Hofmann F, Ammendola A, Schlossmann J (2000) Rising behind NO: cGMP-dependent protein kinases. J Cell Sci 113:1671-1676.

Hope B, Kosofsky B, Hyman SE, Nestler EJ (1992) Regulation of immediate early gene expression and AP-1 binding in the rat nucleus accumbens by chronic cocaine. Proc Natl Acad Sci USA 89:5764-5768.

Humblot N, Thiriet N, Gobaille S, Aunis D, Zwiller J (1998) The serotonergic system modulates the cocaine-induced expression of the immediate early genes egr-1 and c-fos in rat brain. Ann NY Acad Sci 844:7-20.

Jarchau T, Hausler C, Markert T, Pohler D, Vanderkerckhove J, De Jonge HR, Lohmann SM, Walter U (1994) Cloning, expression, and in situ localization of rat intestinal cGMP-dependent protein kinase II. Proc Natl Acad Sci USA 91:9426-9430.

Jouvert P, Dietrich JB, Aunis D, Zwiller J (2002) Differential rat brain expression of EGR proteins and of the transcriptional corepressor NAB in response to acute or chronic cocaine administration. Neuromol Med 1:137-151.

Kanwal S, Elmquist BJ, Trachte GJ (1997) Atrial natriuretic peptide inhibits evoked catechol-amine release by altering sensitivity to calcium. J Pharmacol Exp Ther 283:426-433.

Kita H, Kitai ST (1988) Glutamate decarboxylase immunoreactive neurons in rat neostriatum: their morphological types and populations. Brain Res 447:346-352.

Koller KJ, Lowe DG, Bennett GL, Minamino N, Kangawa K, Matsuo H, Goeddel DV (1991) Selective activation of the B natriuretic peptide receptor by C-type natriuretic peptide (CNP). Science 252:120-123.

Konradi C, Cole RL, Heckers S, Hyman SE (1994) Amphetamine regulates gene expression in rat striatum via transcription factor CREB. J Neurosci 14:5623-5634.

Koob GF, Bloom FE (1988) Cellular and molecular mechanism of drug dependence. Science 242:715-723.

Kuhar MJ, Ritz MC, Boja JW (1991) The dopamine hypothesis of the reinforcing properties of cocaine. Trends Neurosci 14:299-302.

Lohmann SM, Walter U, Miller PE, Greengard P, De Camilli P (1981) Immunohistochemical localization of cyclic GMP-dependent protein kinase in mammalian brain. Proc Natl Acad Sci USA 78:653-657.

Mailleux P, Zhang F, Vanderhaeghen JJ (1992) The dopamine D1 receptor antagonist SCH-23390 decreases the mRNA levels of the transcription factor zif268 (krox-24) in adult rat intact striatum —an in situ hybridization study. Neurosci Lett 147:182-184.

Marinelli M, White FJ (2000) Enhanced vulnerability to cocaine selfadministration is associated with elevated impulse activity of midbrain dopamine neurons. J Neurosci 20:8876-8885.

Miki N, Kawabe Y, Kuriyama K (1977) Activation of cerebral guanylate cyclase by nitric oxide. Biochem Biophys Res Commun 75:851-856.

Moratalla R, Robertson HA, Graybiel AM (1992) Dynamic regulation of NGFI-A (zif268, egr1) gene expression in the striatum. J Neurosci 12:2609-2622.

Morgan IG, Woolfe LS, Mandel P, Gombos G (1971) Isolation of plasma membranes from rat brain. Biochim Biophys Acta 241:737-751.

Morgan JI, Curran T (1991) Stimulus-transcription coupling in the nervous system: involvement of the inducible proto-oncogenes fos and jun. Annu Rev Neurosci 14:421-451.

Nestler EJ (2001) Molecular basis of long-term plasticity underlying addiction. Nat Rev Neurosci 2:119-128.

Orsini C, Izzo E, Koob GF, Pulvirenti L (2002) Blockade of nitric oxide synthesis reduces responding for cocaine self-administration during extinction and reinstatement. Brain Res 925:133-140.

Ouimet CC, Miller PE, Hemmings Jr HC, Walaas SI, Greengard P (1984) DARPP-32, a dopamine- and adenosine $3^{\prime}, 5^{\prime}$-monophosphate-regulated phosphoprotein enriched in dopamine-innervated brain regions. III. Immunocytochemical localization. J Neurosci 4:111-124.

Paxinos G, Watson C (1997) The rat brain in stereotaxic coordinates, Ed 3. Orlando: Academic.

Perese DA, Ulman J, Viola J, Ewing SE, Bankiewicz KS (1989) A 6-hydroxydopamine-induced selective parkinsonian rat model. Brain Res 494:285-293.

Poulain L, Ziller C, Muller CD, Erbacher P, Bettinger T, Rodier JF, Behr JP (2000) Ovarian carcinoma cells are effectively transfected by polyethylenimine (PEI) derivatives. Cancer Gene Ther 7:644-652.

Pudiak CM, Bozarth MA (2002) The effect of nitric oxide synthesis inhibition on intravenous cocaine self-administration. Prog Neuropsychopharmacol Biol Psychiatry 26:189-196.

Rodriguez-Pascual F, Miras-Potugal MT, Torres M (1996) Effect of cyclic GMP- increasing agents nitric oxide and c-type natriuretic peptide on bovin chromaffin cell function: inhibitory role medited by cyclic GMPdependent protein kinase. Mol Pharmacol 49:1058-1070.

Ruth P, Wang GX, Boekhoff I, May B, Pfeifer A, Penner R, Korth M, Breer H, Hofmann F (1993) Transfected cGMP-dependent protein kinase suppresses calcium transients by inhibition of inositol 1,4,5-trisphosphate production. Proc Natl Acad Sci USA 90:2623-2627.

Samson WK, Huang FL, Fulton RJ (1993) C-type natriuretic peptide mediates the hypothalamic actions of the natriuretic peptides to inhibit luteinizing hormone secretion. Endocrinology 132:504-509.

Schmidt HH, Walter U (1994) NO at work. Cell 78:919-925.

Sheng M, Greenberg ME (1990) The regulation and function of c-fos and other immediate early genes in the nervous system. Neuron 4:477-485.

Tanda G, Pontieri FE, Frau R, Di Chiara G (1997) Contribution of blockade of the noradrenaline carrier to the increase of extracellular dopamine in the rat prefrontal cortex by amphetamine and cocaine. Eur J Neurosci 9:2077-2085.

Telegdy G, Kokavszky K, Nyerges A (1999) Action of C-type natriuretic peptide $(\mathrm{CNP})$ on passive avoidance learning in rats: involvement of transmitters. Eur J Neurosci 11:3302-3306.

Thiriet N, Humblot N, Burgun C, Aunis D, Zwiller J (1998) Cocaine and fluoxetine induce the expression of the hVH-5 gene encoding a MAP kinase phosphatase. Mol Brain Res 62:150-157.

Thiriet N, Jouvert P, Gobaille S, Solov'eva O, Gough B, Aunis D, Ali S, Zwiller J (2001) C-type natriuretic peptide (CNP) regulates cocaine-induced 
dopamine increase and immediate early gene expression in rat brain. Eur J Neurosci 14:1702-1708.

Thiriet N, Aunis D, Zwiller J (2002) The nitric oxide releasing agent sodium nitroprusside modulates cocaine-induced immediate early gene expression in rat brain. Ann NY Acad Sci 965:47-54.

Torres G, Rivier C (1994) Induction of c-fos in rat brain by acute cocaine and fenfluramine exposure: a comparison study. Brain Res 647:1-9.

Tsou K, Snyder GL, Greengard P (1993) Nitric oxide/cGMP pathway stimulates phosphorylation of DARPP-32, a dopamine- and cAMP-regulated phosphoprotein, in the substantia nigra. Proc Natl Acad Sci USA 90:3462-3465.

Uhler MD (1993) Cloning and expression of a novel cyclic GMP-dependent protein kinase from mouse brain. J Biol Chem 268:13586-13591.
Walaas SI, Girault JA, Greengard P (1989) Localization of cyclic GMPdependent protein kinase in rat basal ganglia neurons. J Mol Neurosci $1: 243-250$

West AR, Grace AA (2000) Striatal nitric oxide signaling regulates the neuronal activity of midbrain dopamine neurons in vivo. J Neurophysiol 83:1796-1808.

White RE, Lee AB, Shcherbatko AD, Lincoln TM, Schonbrunn A, Armstrong DL (1993) Potassium channel stimulation by natriuretic peptides through cGMP-dependent dephosphorylation. Nature 361:263-266.

Zhuo M, Hu Y, Schultz C, Kandel ER, Hawkins RD (1994) Role of guanylyl cyclase and cGMP-dependent protein kinase in long-term potentiation. Nature 368:635-639. 